\title{
Librarians and Current Research Publication
}

$\mathbf{S}^{\text {CiEntific and technological periodicals }}$ $\mathcal{S}$ contain the ideas upon which our present civilization is based, yet one hears the research man say that he can keep abreast of the literature in his own field only with the greatest of difficulty. Even the largest libraries have to restrict the limits of their collections. Scientists and technologists have inaugurated abstracting journals; librarians have compiled union lists, systematized interlibrary loans and reproducing services. Could it be that these are serviceable, transitional devices to handle a system of publication which has too narrow a basis for the great development we expect? Are we not now ready, as librarians, to make a complete survey of the situation and, with the aid of expert businessmen, to formulate a concrete plan which will render knowledge resources more accessible and which we can recommend to the publishing bodies?

The unit of the literature in question is the individual article, not the journal in which it is published. There are four important features in such an article: $I$. the subject matter; 2 . the author and his sponsor; 3 . the date; 4 . the editorship. Why not publish with only these factors in mind? It might be worked out in the following manner.

An author sends his article and an abstract of it to his usual editors. When both article and abstract have received editorial approval they are sent to a central printing office. The head printer gives both one master number in chrono- logical order of receipt and passes them on to receive as many classification numbers and index entries as necessary. A cost accountant sets the purchase price on the article and notes the number of copies to be made. The cost is covered by the cooperating societies paying to the central printing office the same amount of money as formerly used for publication. The articles and abstracts then go to the printing room. The "printing room" probably would mean numerous printing establishments, each covering one phase of science or technology.

At weekly intervals two types of publications come out of the printing room. I. A series of separate riginal articles of uniform size, with author, title, date, authorizing organization, master numbers, classification number or numbers, and price on them. 2. An abstract-index journal made up of four lists-(a) An alphabetical list of authors and titles, (b) a master number list, (c) an authorizing organization list giving the articles so sponsored, and (d) the abstracts themselves arranged by classified subject, an abstract appearing in full under each classification in which it is significant. The full abstract-index journal and each of its sections would have fixed subscription charges. The original articles, as a series, would be subscribed for by subject, while individual articles could be purchased with the use of coupons such as the U.S. Superintendent of Documents Office issues.

It is obvious that, in suggesting such a 
system of publication, librarians are not encroaching upon the prerogatives of the authors or their societies. They are simply proposing an improvement in the mechanics of printing and distribution, a purely business matter. The printing, paper buying, classifying, and indexing would be done uniformly by specialists. Such a system would speed up publication and would obviate the making of abstracts by various agencies whose services now overlap. There would be but one central source for ordering and reordering. It would have all the advantages of mass production, so far as printing and indexing are concerned, without imposing regimentation of thought.

The scientist and technologist are justly proud of the journals they have developed. We as librarians give as good service as we can under the present conditions, but isn't it our duty to offer suggestions whereby the conditions can be improved?

Zeliaette Troy
Aydelotte, Frank. Breaking the Academic Lock Step; the Development of Honors Work in American Colleges and Universities. New York City, Harper, 1944.

To abandon the ideals of liberal education would mean that in winning the war we had given up all that we are fighting for and it would be furthermore a tragic misreading of the lesson which we ought to learn from the issue of the conflict.Page 6.

Only by education can we translate into practice the great aims for which we have been fighting. Those aims are in the last analysis intellectual and spiritual. They can never be realized by the mere mastery of scientific and engineering and economic techniques. They can never be realized by turning men into machines, even though food, clothing, shelter, and amusements are guaranteed.-Page 9.

While seeing to it that individuals of each level of ability have the training best suited to them, we must realize that the future of our country depends upon what happens to the best. It is from the ablest young men and women, given the proper training, that we may hope for the leadership without which democracy cannot survive.Page 10.

It requires courage in a democracy like ours, which considers each man as good as his neighbor, if not a little better, to put into operation what seems to many an aristocratic method of education. But we must learn to see the error in that superficial interpretation of democracy which assumes that all men are equal in intellectual ability. We must understand that in recognizing individual differences we are paying the truest homage to the worth of all individuals.-Page $I I$.

Edwards, Marcia. Studies in American Graduate Education, a Report to the Carnegie Foundation. New York City, 1944 .

The present may well be the appropriate time for individual graduate schools to review their respective aims, inquire into their own conditions, and seize upon the principles and the implements that most promise improvement. This is not to say that uniformity in administrative procedures, standards, or devices is to be sought; the regimentation that such a uniformity would imply, even if self-imposed among the schools, would be as impossible as it would be undesirable. It is to suggest that sincerity, discriminating judgment, and wisdom in the interpretation and application of clearly perceived principles are of first importance in the future of our graduate education.-Page $x v i$.

(Continued on page 245) 
and refund his payment, if any.

Upon receipt of the order, the cooperating library to which it is forwarded may either send an estimate, requesting payment in advance, or may furnish the reproduction together with a bill for the service, if that is in accordance with its policy.

\section{General Provisions}

It is agreed that each cooperating library:

I. May limit the number of periodical articles it will copy under this agreement.

2. Reserves the right to refuse any order which requires more than fifteen minutes of reference work.

3. Reserves the right to refuse any order which does not conform to its own copying policy.
4. Will perform the work requested or report upon it within two weeks from the date of receipt of the order.

5. Will verify each reference it sends to another library and will not transmit any order unless there is evidence that the library to which it is forwarded has the material requested (i.e., as shown in the Union List of Serials or other guides to holdings).

6. Will reserve the right to supply photoprints, if it elects to do so, in lieu of microfilm in those cases in which photoprints can be supplied for fifty cents.

7. Reserves the right to limit the length of any article supplied for fifty cents under this agreement to not more than fifty pages, if it wishes to do so.

Ralph R. Shaw

\section{Librarians and Current Research Publication}

(Continued from page 243)

White, Carl M. "The Battle of the Books." (In Vital Speeches, Mar. I, 1944, p. 316-20.)

"H. G. Wells, writing just after the last war, described the situation of humanity at that time as a race between education and catastrophe. As we all know, catastrophe won the race. But if the United Nations win this war, education has one more chance.... If we lose the next race, the next catastrophe will be a bigger and better catastrophe which might close this phase of the development of the human species. ..."-Page 320.

Finally, the waging of the battle of books has a bearing on public policy. It falls outside my present purpose to describe how intellectual or cultural services relied on so heavily by the modern world unofficially can better be fitted into the framework of official policy. But the conclusion that public action normally follows pretty closely the thinking of literate people, and that the thinking of literate people normally follows the most powerful intellectual forces of the times, has some inescapable implications. It implies a policy of recognizing and systematically developing intellectual leadership of high order. It implies a policy of protecting and supporting all those professionally concerned with ideas who show intellectual integrity and a sense of public responsibility. It implies a policy of keeping accessible to the public the sources of information-the press, the open forum, and that increasingly important source of all kinds of information, the modern library.-Page 320. 